Souza, F.S. and Fontanini, P.S.P. 2020. "Impact on Productive Stability Caused by Variations of Prestressed Precast Elements." In: Tommelein, I.D. and Daniel, E. (eds.). Proc. $28^{\text {th }}$ Annual Conference of the International Group for Lean Construction (IGLC28), Berkeley, California, USA, doi.org/10.24928/2020/0097, online at iglc.net.

\title{
IMPACT ON PRODUCTIVE STABILITY CAUSED BY VARIATIONS OF PRESTRESSED PRECAST ELEMENTS
}

\author{
Felipe S. Souza ${ }^{1}$ and Patricia S.P. Fontanini ${ }^{2}$
}

\begin{abstract}
Precast elements have prominence in Brazilian civil construction in recent years. Because the production of structural parts is industrialized, this segment has provided a product with better quality control and technological performance. In the current economic situation in Brazil, the market has few opportunities, decreasing sales prices, and profits, in addition to constant pressure for more efficient manufacturing. In this approach, many companies choose to use lean construction, looking for an opportunity to maximize the added value of the product for customers, reduce waste, generate quality, and produce in a continuous flow. However, the sector is still characterized by the significant variation in demand, which is a reflection of the market with differences in typology (pieces) requested in the construction. A low standardization of projects, flows, and workloads vary throughout the month, hinders productive stability and the implementation of lean production. The present research adopted the Action Research methodology, proposing to stabilize the production of precast prestressed beams. In the stabilization process, it was possible to identify the impact caused by production variations on basic stability, assuming to propose processes to be improved within this production line.
\end{abstract}

\section{KEYWORDS}

Standardization, prestressed precast elements, variability, action research

\section{INTRODUCTION}

With a mission of not declaring Toyota bankruptcy, Ohno performs improved improvements within its production. Such improvements reduced waste, reduced production costs and added value to the product, which gave rise to the Toyota Production System (Ohno, 1997).

The precast elements, when compared to conventional construction, provide greater quality, structural performance, and technological control. Industries in this segment seek to maintain their production close to the allowed capacity (when required), being necessary to compose production according to the "MIX" of parts requested by the market. The industries suffer direct interference from the construction typologies (shed, shopping

1 Master, Laboratory of Systems Technology and Construction Processes (LABTEC), University of Campinas (UNICAMP) and Precast Production Coordinator, Sudeste Pré-Fabricados LTDA, souzafelipesantos@gmail.com, orcid.org/0000-0002-0359-0427

2 Professor, Laboratory of Systems Technology and Construction Processes (LABTEC), Department of Architecture and Building, School of Civil Engineering, Architecture and Urban Design, University of Campinas, Brazil (UNICAMP), patricia@fec.unicamp.br, orcid.org/0000-0002-7532-7505 
mall, shopping centers, hotels, etc.), being applied to nature and changeable by the construction industry (Asgari, Kheyroddin, and Naderpour 2017).

With recession economic in the civil construction sector, many companies are looking for increasingly to make your production more efficient alternatives, with more controlled material and manufacturing costs (Wang et al. 2012). Due to Toyota's remarkable success (Womack, Jones, and Ross 1998), many companies in the precast sector have tried to replicate lean thinking; however, in the vast majority, without success. According to the PCI-Precast Concrete Institute (2006), when analyzing companies that tried to implement an STP, they found that approximately $90 \%$ do not succeed; between $5 \%$ and $7 \%$ of companies tried to persist, but without substance; and only $3 \%$ to $5 \%$ of companies transform or not the production and business of companies.

According to Rother (2010), the first step in making processes leaner is to stabilize activities, generating trust and synchronicity between them, which would allow the implementation of a continuous flow. The stabilization process is more difficult within the civil construction, as this sector presents several peculiarities such as unbalanced workloads, different setups (changing shapes and readjusting unique and special projects), and a high rate of absenteeism in the hand of work (Bulhões, Picchi, and Folch 2006).

\section{BASIC STANDARDIZATION}

The Civil Construction sector presents complex flows in the production processes (Picchi 2001), with a high degree of interruptions and imbalances in production capacity, which hinders the overall stability of the segment's enterprises. The stability is determined by the degree of confidence in the production line, with the consistency of the length of time, the method of execution and the quality of a respective activity, allowing the synchronization between the processes.

Samaniego (2006) adopts basic stability as the first level of attainable stability. This stability must have a minimum constancy of $4 \mathrm{Ms}$ (Material, Method, Labor, and Machines) to follow the planned sequence, availability, and little variation in the execution time. This stability is a minimum requirement in a lean production line, avoiding the impact on the continuous flow and in-process stock (Smalley 2005). As shown in Figure 1, each of the 4Ms must meet the basic requirements to obtain productive stability.

\section{METHODOLOGY}

In this research, the Action Research (AR) methodology was adopted. This methodology generates knowledge production guided by practice, allowing researchers to take an active role in balancing the problems encountered. In this way, an AR allows the researcher, who is also the production coordinator of the studied company, to modify the reality found with the scientific results to solve a practical problem (Thiollent 2007; Oquist 1978; Bryman 1989). 


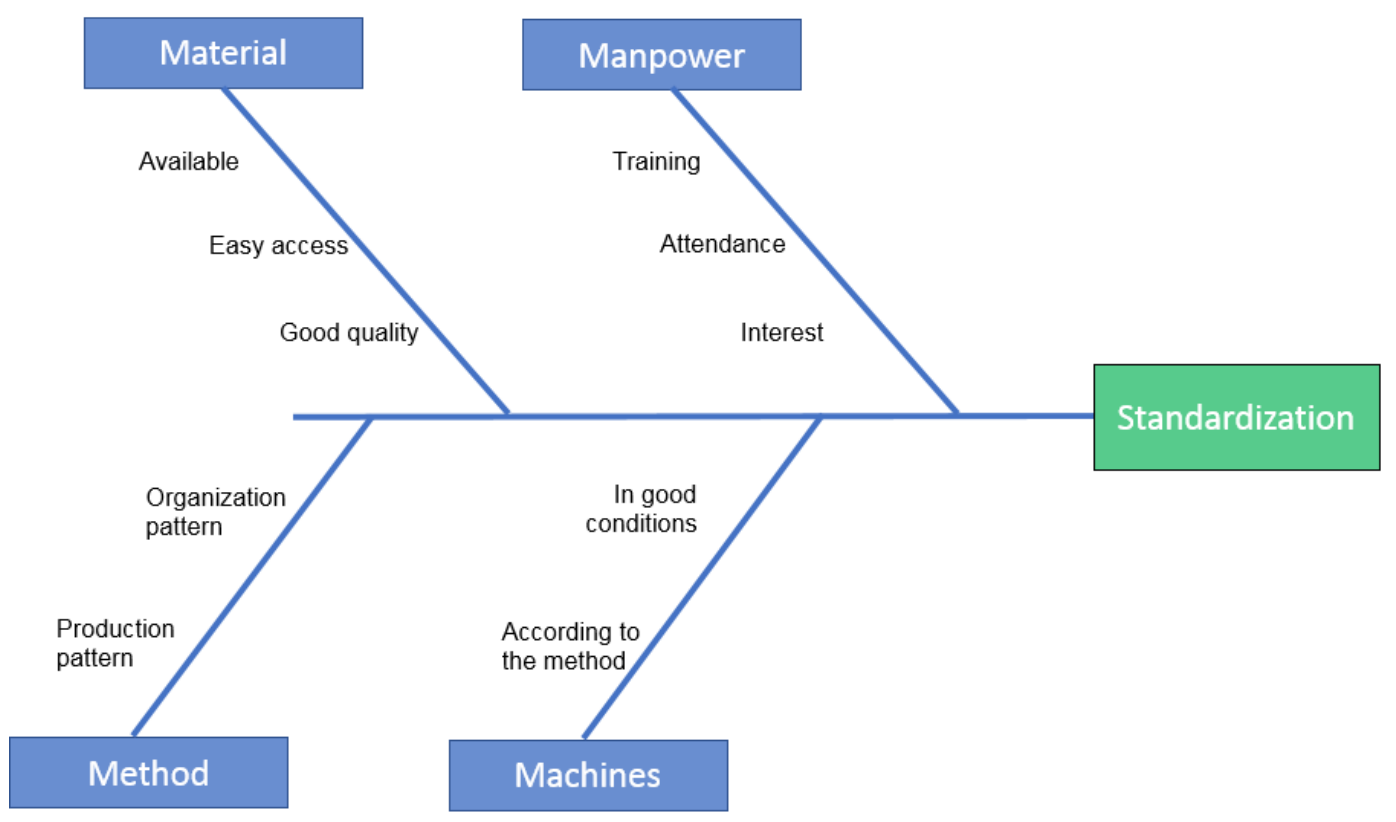

Figure 1: Diagram of the cause-effect of the 4Ms (extracted from Samaniego 2006)

The research was carried out at Factory A, located on the State of São Paulo (Brazil), with a capacity of 5,300 $\mathrm{m}^{3}$. It was producing $4,000 \mathrm{~m}^{3}$ with 320 employees during the research period. Their products are pillars, beams, and strutting beam as structural elements; solid closing panel and custom parts. The company presents itself for its great productive adaptation, varying its formats according to the needs of its customers. One company in question has level III (three) certification from the Brazilian Association of Industrial Concrete Construction (ABCIC), producing works of the warehouses, hospitals, shopping centers, hotels and supermarkets, using precast elements.

As the first stage of a master's research, a survey of tracks and duration of activities was carried out on 17 production lines of rectangular beams for four months. In an attempt to establish the process, adapted standardized works (SW) were elaborated, with durations, methods, and sequences of activities. It was possible to divide the stages into small activities, allowing being observed specific characteristics of the production track that directly interfere in durations. Inside the factory, the beams go through the steps of reinforced steel, production and finishing of the beams. The production stage is subdivided into more than seven sub-stages: preparation, the passage to string prestressed steel, protection, assembly, closure, concreting, curing, opening and withdrawal. This research studied only preparation, assembly, and closing sub-steps.

\section{DATA SURVEY}

The researchers followed the execution of the preparation, assembly, and closing substeps, allowing to detail all the activities present, with feasible sequences and methods. This research stage allowed to identify the characteristics of the pieces that directly interfered in the duration of the activities, being:

- Number of inserts: number of accessories for various connections between precast parts or other production systems, such as metal roofs/closures or wood; 
- Number of beams: number of pieces may vary according to the length since the track has a length limited to $100 \mathrm{~m}$;

- Number of cables: they vary according to the project to meet the load the pieces;

- Length of the track: the length of the track directly affects the number of molds to be cleaned, assembled and locked (Figure 2);

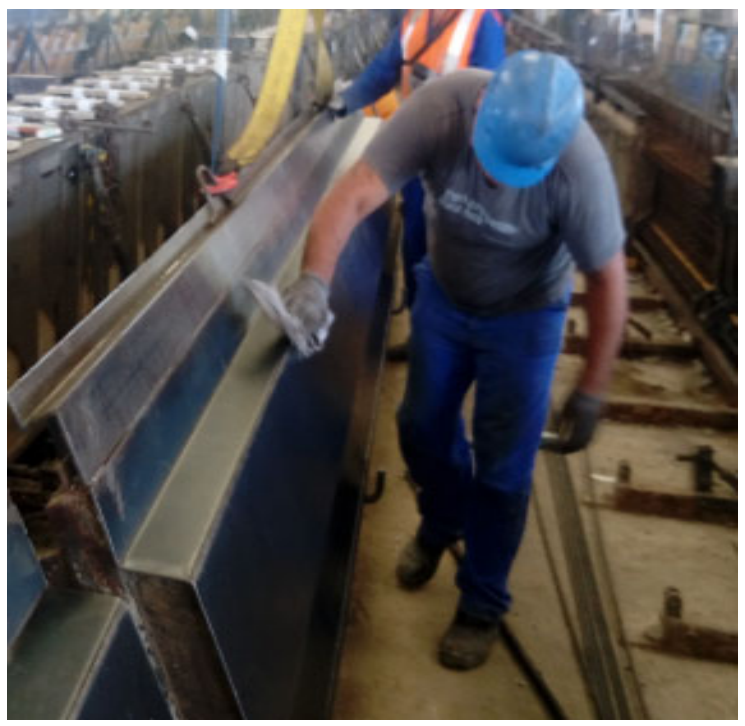

Figure 2: Cleaning of the molds

- Length of the track with tab: specific assembly step that requires a long duration, in the wood sheet for concreting a capping piece (the tab serves as a form for the hollow core slab in precast (Figure 3);

- Volume of concrete: varies according to the geometry of the pieces, interfering in the concreting time;

- Weight of reinforced steel: the rate of steel varies depending on the project, respecting the load and length of the beams. A higher rate can make it difficult for assembly and cables to pass. 

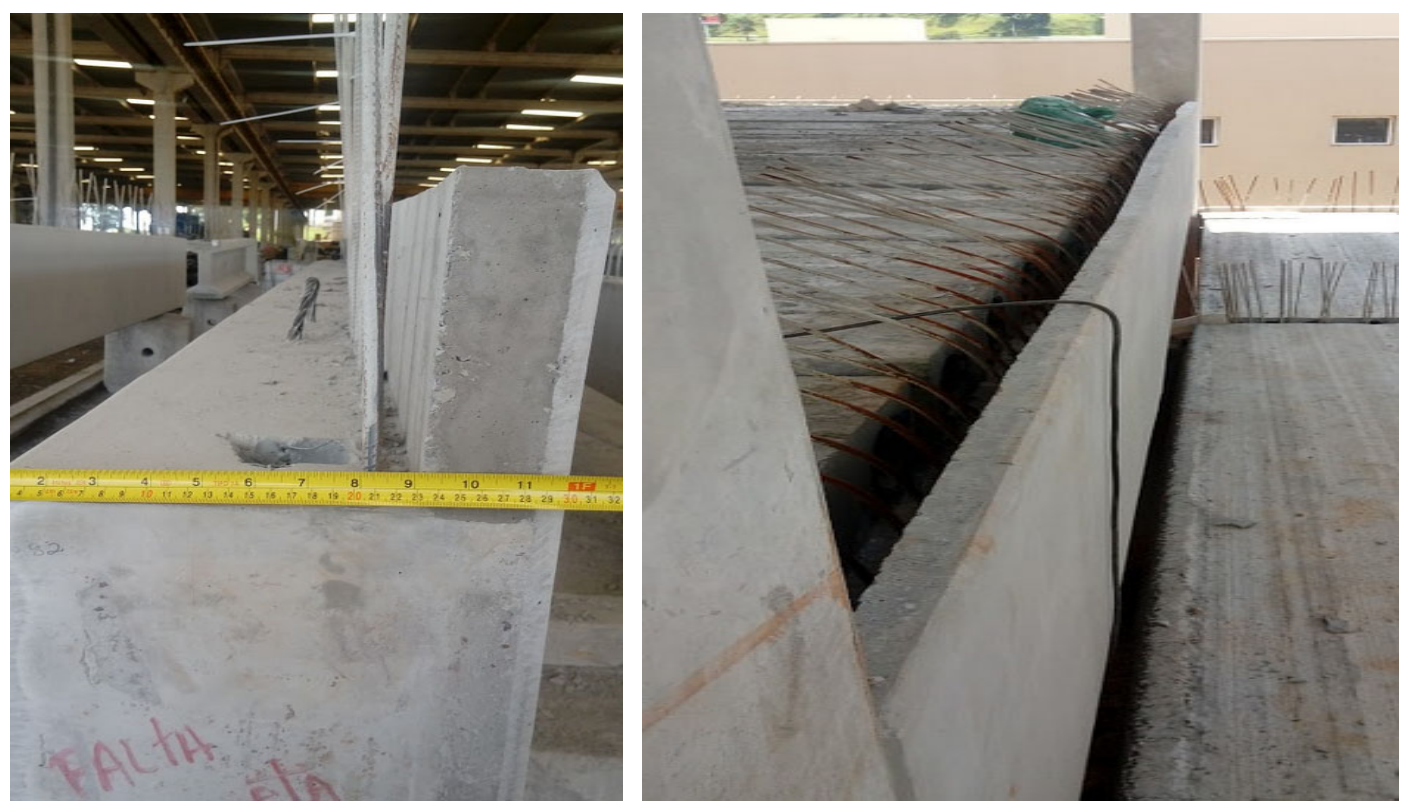

Figure 3: Beam with tab

To focus the research, a single production track was studied, which made prestressed rectangular beams. For four months, it was necessary to note the characteristics of the tracks produced. In parallel, the duration of activities was estimated and the production was timed according to the guidelines of Rother and Harris (2002), adapting a Standardized Work Composition Table (TCTP). The researcher observed the initial displacement of the work team, the number of employees present in the execution of the activity, and ten times the time. The average time was considered as the duration time. During the surveys, the times were recorded according to the characteristic that directly interfered in the duration, receiving the name of interference characteristic. Some activities were surveyed according to the size of a module, for example, time to time to close a $6 \mathrm{~m}$ metal mold. The final time was proportional to the time taken, due to the number of employees divided by the $6 \mathrm{~m}$ module. In this case, we would have as a result, the time spent per hour.meter / man.

\section{RESULTS}

Table 1 shows the characteristics of the production ranges of the 17 tracks surveyed during the four months of research. From the data, it is possible to identify that no characteristics remained constant throughout the investigation. 
Table 1: Characteristics of the track

\begin{tabular}{|c|c|c|c|c|c|c|c|c|}
\hline \multirow{2}{*}{ TRACK } & \multicolumn{3}{|c|}{ LENGTH $(\mathrm{m})$} & NUMBER & NUMBER & NUMBER \\
OF \\
\cline { 2 - 8 } & $\begin{array}{c}\text { WITHOUT } \\
\text { TAB }\end{array}$ & WITH TAB & TOTAL & $\begin{array}{c}\text { NOMSERTS } \\
\text { OF BEAMS }\end{array}$ & OF CABLES & $\begin{array}{c}\text { WEIGHT OF } \\
\text { REIFORCED } \\
\text { INTEEL (kg) }\end{array}$ \\
\hline dez/04 & 0,0 & 94,1 & 94,1 & 2,0 & 10,0 & 10,0 & 21,3 & 3047,0 \\
\hline dez/06 & 12,3 & 67,0 & 79,3 & 4,0 & 10,0 & 8,0 & 13,1 & 2411,5 \\
\hline dez/11 & 15,3 & 70,4 & 85,6 & 9,0 & 11,0 & 10,0 & 19,2 & 2814,6 \\
\hline dez/13 & 58,3 & 36,4 & 94,7 & 0,0 & 10,0 & 8,0 & 20,9 & 2438,0 \\
\hline dez/18 & 70,6 & 19,0 & 89,6 & 0,0 & 11,0 & 3,0 & 16,3 & 2303,0 \\
\hline dez/20 & 0,0 & 93,8 & 93,8 & 0,0 & 13,0 & 5,0 & 16,6 & 2255,8 \\
\hline jan/09 & 39,9 & 54,7 & 94,6 & 0,0 & 11,0 & 8,0 & 21,1 & 2870,1 \\
\hline jan/15 & 56,0 & 39,6 & 95,6 & 3,0 & 17,0 & 7,0 & 16,0 & 2006,5 \\
\hline jan/19 & 14,6 & 70,7 & 85,3 & 0,0 & 13,0 & 5,0 & 14,5 & 1350,7 \\
\hline jan/25 & 70,3 & 7,9 & 78,2 & 1,0 & 9,0 & 12,0 & 17,1 & 3346,4 \\
\hline jan/30 & 45,4 & 5,5 & 50,9 & 4,0 & 9,0 & 5,0 & 7,6 & 810,1 \\
\hline feb/02 & 51,8 & 25,4 & 77,3 & 0,0 & 9,0 & 9,0 & 13,7 & 194,2 \\
\hline feb/06 & 67,0 & 0,0 & 67,0 & 0,0 & 9,0 & 6,0 & 12,0 & 1390,1 \\
\hline feb/12 & 66,6 & 0,0 & 66,6 & 0,0 & 9,0 & 6,0 & 14,9 & 1385,2 \\
\hline mar/13 & 71,3 & 0,0 & 71,3 & 6,0 & 11,0 & 4,0 & 12,3 & 1501,3 \\
\hline mar/21 & 74,5 & 13,7 & 88,2 & 0,0 & 11,0 & 8,0 & 16,0 & 2408,7 \\
\hline apr/19 & 89,7 & 0,0 & 89,7 & 0,0 & 9,0 & 5,0 & 18,8 & 2333,9 \\
\hline AVERAGE 0F & 47,3 & 35,2 & 82,5 & 1,7 & 10,7 & 7,0 & 16,0 & 2051,0 \\
\hline CHARACTERISTICS & & & & & & & & \\
\hline
\end{tabular}

The preparation, assembly, and closing sub-stages had their activities studied, allowing to identify their estimated duration. This duration is the sum of the times of the activities present in each substage, as can be seen in Table 2. 
Table 2: Survey of the assembly step process times

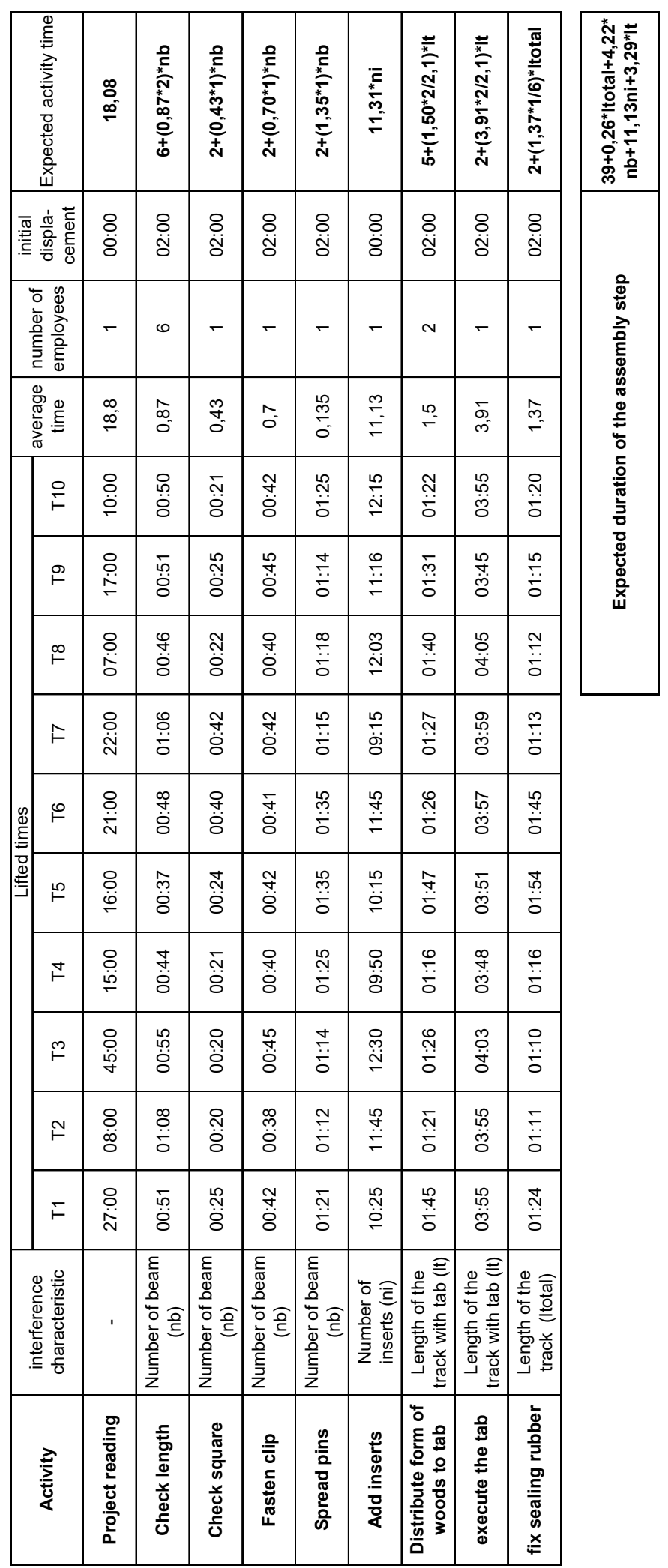




\section{IMPACT OF CHANGES}

Considering these characteristics and comparing the estimated duration of the preparation, assembly, and closing stages, the theoretical impact of variations within this production line was verified. According to Table 3, when we compare the shorter duration time, respectively, with the longer duration time, for the preparation, assembly and closing substages, we have a percentage variation of $70 \%, 241 \%$, and $43 \%$, respectively.

Table 3: Influences of characteristics on production time

\begin{tabular}{|c|c|c|c|}
\hline TRACK & $\begin{array}{c}\text { STEPS OF } \\
\text { PREPARATION } \\
(\mathrm{min})\end{array}$ & $\begin{array}{c}\text { STEPS OF } \\
\text { ASSEMBLY } \\
(\mathrm{min})\end{array}$ & $\begin{array}{c}\text { STEPS OF } \\
\text { CLOSING } \\
(\mathrm{min})\end{array}$ \\
\hline $\mathrm{dez} / 04$ & 717,23 & 1313,35 & 790,80 \\
\hline $\mathrm{dez} / 06$ & 653,68 & 1112,36 & 672,56 \\
\hline $\mathrm{dez} / 11$ & 701,54 & 1280,75 & 725,20 \\
\hline $\mathrm{dez} / 13$ & 719,72 & 751,54 & 795,44 \\
\hline $\mathrm{dez} / 18$ & $7,18,87$ & 631,17 & 757,44 \\
\hline $\mathrm{dez} / 20$ & 778,52 & 1370,15 & 768,60 \\
\hline $\mathrm{jan} / 09$ & 740,07 & 957,63 & 769,88 \\
\hline $\mathrm{jan} / 15$ & 869,66 & 1096,45 & 819,52 \\
\hline $\mathrm{jan} / 19$ & 741,84 & 1149,89 & 727,36 \\
\hline $\mathrm{jan} / 25$ & 628,09 & 493,76 & 661,36 \\
\hline $\mathrm{jan} / 30$ & 510,57 & 524,50 & 442,72 \\
\hline $\mathrm{feb} / 02$ & 624,04 & 622,49 & 653,84 \\
\hline $\mathrm{feb} / 06$ & 579,71 & 401,34 & 571,36 \\
\hline $\mathrm{feb} / 12$ & 577,99 & 401,14 & 568,16 \\
\hline $\mathrm{mar} / 13$ & 640,18 & 602,82 & 611,04 \\
\hline $\mathrm{mar} /$ & 715,55 & 587,23 & 745,68 \\
\hline $\mathrm{apr} /$ & 677,49 & 412,71 & 753,28 \\
\hline
\end{tabular}

\section{DISCUSSION}

Factory management The aim is to carry out all stages of production until concreting within working hours, allowing the concrete curing activity to take place during the night. With a wide variation in the duration of activities, it was possible to observe that, throughout the research, some more complex trails were not completed by the end of the day, impacting on:

- At the beginning of the day, the production team works to finish a delayed track instead of starting a new one;

- Great variation in the routine of this team;

- Failure in programming, with beam structures ready to be produced while a production team waited for curing of delayed parts;

- Unevenness between the processes of reinforced steel, production and finishing of beams; and

- When the available time was not enough for the complete completion of the tracks, some processes were run over, generating a high index of defects. 
According to Rother and Harris (2002) within a family of parts there should be no variation greater than $30 \%$. This shows the difficulty in defining a routine and stabilizing this production process. According to the researched results, this variation directly interferes in the lean implementation, making it challenging to implement a continuous flow, standardized jobs, and Takt-time.

To reduce the impact caused by the changes, the following are recommended: (1) deepen the study of the project to try to match the characteristics of the parts, decrease the size of the production runway, divide an original $100 \mathrm{~m}$ runway into two smaller runways of $50 \mathrm{~m}$; (2) separate better these two tracks as families of parts to reduce changes in parts of the same track, level the difficulty of the beams present in the production tracks and invest in automation in the steps that generate the greatest variation, such as the execution of a tab in the beam.

\section{CONCLUSIONS}

With the case study carried out, it was possible to verify the greater impact of the productive variations in the prestressed precast production pieces. In the assembly stage, production showed a variation equal to $241 \%$ to the fastest track with the longest.

This variation interferes with the production management of precast elements, imposing difficulties to stabilize and level the production of processes, guarantee first-infirst-out (FIFO) flows, quickly identify the best workflow and dimension the real productive capacity concerning the current MIX of parts.

These encountered difficulties directly interfere in lean implementation, being necessary to carry out a work to reduce the variations: to improve the division of the productive families; investing in more automated solutions; an analysis of the process steps and design solutions that better serve the "MIX" of parts and typologies requested by the market. It is suggested as future research, an in-depth study of changes in the product layout and design specifications to allow for a reduction in these variations.

\section{ACKNOWLEDGMENTS}

We are grateful to Factory A for allowing data collection and to the entire team of the Laboratory of Systems Technology and Construction Processes (LABTEC) at the State University of Campinas, Faculty of Civil Engineering, Architecture and Urbanism for supporting the development of this research.

\section{REFERENCES}

Asgari, M., Kheyroddin, A., Naderpour, H. 2017. "A Proposal Model for Estimation of Project Success in Terms of Radial Based Neural Networks: A Case Study in Iran." Civil Engineering Journal, v. 03, pp. 904-919.

Bryman, A. (Ed.). (1989). Research methods and organization studies. Contemporary Social Research, London.

Bulhões, I. R., Picchi, F. A., Folch, A. T. 2006. "Actions to implement continuous flow in the assembly of prefabricated concrete structure." Proc. 14th Annual Conference of the International Group for Lean Construction (IGLC14). Santiago, Chile, pp. 407419

Ohno, T. O 1997. Toyota Production System: beyond large scale production. Taylor \& Francis: London, UK 
O'Quist, P. 1978. “The epistemology of action research.” Acta Sociologica. v. 21, n. 2, pp. 143-163.

Picchi, F. A. 2001 "System view of Lean construction application opportunities." Proc. 9th Annual Conference of the International Group for Lean Construction (IGLC9). Singapore, Singapore, pp. 6-8.

Ray, B., Ripley, P., Neal, D. 2006. "Lean Manufacturing A Systematic Approach to Improving Productivity in the Precast Concrete Industry." PCI Journal, p. 62-71.

Rother, M., Harris, R. 2002. Creating the continuous flow: an action guide for managers, engineers and production associates. Lean Enterprise Institute: MA, USA.

Rother, M. 2010. Toyota Kata: Managing People for Improvement, Adaptability and Exceptional Results. Lean Enterprise Institute: MA, USA.

Samaniego, C. A. G. Granja, A. D., Picchi, F. A., Folch, A. T. 2014. "Stabilization and Standardization of Precast Production Process." Proc. 14th Annual Conference of the International Group for Lean Construction (IGLC14). Santiago, Chile, pp. 205-213

Smalley, A. 2005. "The starting point for Lean manufacturing: Achieving basic stability." Management Services, v. 49, n. 4, pp. 8-12.

Thiollent, M. 2007. Action research methodology. Brazil.

Wang, C. Liu, M., Hsiang, S. M., Leming, M. L. 2012. "Causes and Penalties of Variation: Case Study of a Precast Concrete Slab Production Facility." Journal of Construction Engineering and Management, v. 138, n. 6, pp. 775-785.

Womack, J. P., Jones, D. T., Roos, D. 1998. The machine that changed the world. Simon and Schuster, London, UK 
Felipe S. Souza and Patricia S.P. Fontanini

This page was intentionally left blank. 
Impact on Productive Stability Caused by Variations of Prestressed Precast Elements

This page was intentionally left blank. 